\title{
Genome Size and Deoxyribonucleic Acid Base Composition of Thermoplasma acidophilum
}

\author{
CLAUS CHRISTIANSEN, E. A. FREUNDT, AND FINN T. BLACK \\ FAO/WHO Collaborating Centre for Animal Mycoplasmas, Institute of Medical Microbiology, \\ University of Aarhus, DK-8000 Aarhus C, Denmark
}

The deoxyribonucleic acid base composition of two strains of Thermoplasma acidophilum including the type strain 122-1B2 was determined by buoyant density and thermal denaturation temperature. The guanine plus cytosine content of the two strains examined was found by both methods to be about $46 \%$. This result is strikingly at variance with the significantly lower values, about $25 \%$, reported by the group of workers who first described this organism. The genome size, as determined by the renaturation method of Wetmur and Davidson, was found to be about $10^{9}$ daltons. This is identical with the genome size of members of the family Acholeplasmataceae, order Mycoplasmatales, within which order $T$. acidophilum has been tentatively classified.

Darland et al. (5) in 1970 described in obligately thermophilic and acidophilic organism, Thermoplasma acidophilum, isolated from a coal refuse pile. The tentative classification of this new organism in the order Mycoplasmatales was based, inter alia, on the absence of a rigid cell wall and on the low content of guanine plus cytosine $(\mathrm{G}+\mathrm{C})$ (about $25 \%$ ) in the deoxyribonucleic acid (DNA).

Not only has the absence of a true cell wall been confirmed (6), but also the composition of the cytoplasmic membrane surrounding $T$. acidophilum has been shown to be very similar to that of the mycoplasma membrane with respect to both glycerol glycolipids and phosphoglycolipids (8) and amino acids (11).

As mentioned briefly in an earlier report (6), we have been unable, on the other hand, to confirm the low $\mathrm{G}+\mathrm{C}$ content found by Darland et al. (5) and subsequently by Belly et al. (2). The purpose of this paper is to present the experimental data forming the basis of the results of determination of the $\mathrm{G}+\mathrm{C}$ content and genome size of $T$. acidophilum previously reported by us.

\section{MATERIALS AND METHODS}

Organisms. The original description of $T$. acidophilum was based on two strains: 122-1B2 and 122-1B3 (5). Strain 122-1B2, ATCC 25905, deposited as the type strain of $T$. acidophilum, was received as a freeze-dried culture from the ATCC (18 October 1971, our reference no. AMRC-C 165). Two different culture lines of strain 122-1B3 were examined, both of which were obtained in the wet state direct from T. D. Brock (21 July 1971, AMRC-C 143; and 17 September 1971, AMRC-C 153)

Growth medium. The growth medium was prepared according to a prescription kindly provided by
T. D. Brock. Salt solution A consisted of (grams/ liter): $\quad \mathrm{FeCA}_{3} \cdot 6 \mathrm{H}_{2} \mathrm{O}, \quad 1.93 ; \quad \mathrm{MnCl}_{2} \cdot 4 \mathrm{H}_{2} \mathrm{O}, \quad 0.18$; $\mathrm{Na}_{2} \mathrm{~B}_{4} \mathrm{O}_{7} \cdot 10 \mathrm{H}_{2} \mathrm{O}, 0.45 ; \mathrm{ZnSO} \cdot 7 \mathrm{H}_{2} \mathrm{O}, 0.022 ; \mathrm{Cu}$. $\mathrm{Cl}_{2} \cdot 2 \mathrm{H}_{2} \mathrm{O}, 0.005 ; \mathrm{NaMoO}_{4} \cdot 2 \mathrm{H}_{2} \mathrm{O} ; 0.003 ; \mathrm{VOSO}_{4}$. $2 \mathrm{H}_{2} \mathrm{O}, 0.003$; and $\mathrm{CoSO}_{4}, 0.001$. Salt solution $\mathrm{B}$ consisted of: $\left(\mathrm{NH}_{4}\right)_{2} \mathrm{SO}_{4}, 13.2 ; \mathrm{KH}_{2} \mathrm{PO}_{4}, 3.72 ; \mathrm{MgSO}_{4}$. $7 \mathrm{H}_{2} \mathrm{O}, 2.47$; and $\mathrm{CaCl}_{2} \cdot 2 \mathrm{H}_{2} \mathrm{O}, 0.74$. A 10 -ml volume of solution $A$ and a $100-\mathrm{ml}$ volume of solution $B$ were mixed into $800 \mathrm{ml}$ of demineralized water, the $\mathrm{pH}$ was adjusted to 2.0 with $10 \mathrm{~N} \mathrm{H}_{2} \mathrm{SO}_{4}$, and water was added to make 1 liter. After autoclaving, stock solutions of yeast extract (Difco) $(10 \% \mathrm{wt} / \mathrm{vol})$ and glucose $(50 \%$ $\mathrm{wt} / \mathrm{vol}$ ) were added to yield final concentrations of 0.1 and $1.0 \%$, respectively.

Cultivation and harvest of organisms. For passage and maintenance cultures, $5-\mathrm{ml}$ volumes of growth medium dispensed in $25-\mathrm{ml}$ screw-capped bottles were inoculated with $0.1 \mathrm{ml}$ of a log-phase culture and incubated at $55 \mathrm{C}$ for $72 \mathrm{~h}$. For largescale production, each of five $1,000-\mathrm{ml}$ samples of prewarmed growth medium, bottled in 2-liter Erlenmeyer flasks, was inoculated with $25 \mathrm{ml}$ of culture incubated as above, and harvested in the Sorvall continuous-flow system at $48,000 \times g$, flow rate 30 $\mathrm{ml} / \mathrm{min}$.

DNA extraction. The DNA was isolated by the method of Marmur (9), as previously described (1).

Determination of $\mathbf{G}+\mathbf{C}$ content. Determination of buoyant density was performed by the method of Schildkraut et al. (10) with DNA extracted from Micrococcus lysodeikticus used as a reference (density $1.732 \mathrm{~g} / \mathrm{cm}^{3}$ ). The melting temperature was determined in SSC (SSC is $0.15 \mathrm{M} \mathrm{NaCl}, 0.015 \mathrm{M}$ trisodium citrate, $\mathrm{pH}$ 7.0) as previously described (4).

Determination of genome size. Determination of genome size was performed by the renaturation method of Wetmur and Davidson (14) with the modifications described by Christiansen et al. (4).

\section{RESULTS}

The results of determinations of the $\mathrm{G}+\mathrm{C}$ content of the DNA and calculations of the 
TABLE 1: DNA base composition and genome size of Thermoplasma acidophilum

\begin{tabular}{|c|c|c|c|c|c|}
\hline \multirow[b]{2}{*}{ Strain } & \multirow[b]{2}{*}{ Source } & \multirow[b]{2}{*}{ Passage no ${ }^{a}$} & \multicolumn{2}{|c|}{$G+C$ from } & \multirow{2}{*}{$\begin{array}{c}\text { Genome size in } \\
\text { daltons }\end{array}$} \\
\hline & & & $\begin{array}{l}\text { Buoyant } \\
\text { density }\end{array}$ & $T_{m}$ & \\
\hline $\begin{array}{l}122-1 \mathrm{~B} 2 \\
(\mathrm{AMRC}-\mathrm{C} 165)^{b}\end{array}$ & ATCC 25905 & 5 & 46.9 & $\mathrm{ND}^{c}$ & $9.4 \times 10^{8}$ \\
\hline $\begin{array}{l}\text { 122-1B3 } \\
\text { (AMRC-C 143) }\end{array}$ & $\begin{array}{l}\text { T. D. Brock } \\
\text { (21 June 1971) }\end{array}$ & 15 & 46.2 & 43.6 & $9.7 \times 10^{8}$ \\
\hline $\begin{array}{l}\text { 122-1B3 } \\
\text { (AMRC-C 153) }\end{array}$ & $\begin{array}{l}\text { T. D. Brock } \\
\text { (17 Sept 1971) }\end{array}$ & 13 & 46.1 & 46.3 & $1.0 \times 10^{9}$ \\
\hline
\end{tabular}

${ }^{a}$ Refers to passages made in this laboratory.

${ }^{\circ}$ Reference number of this laboratory.

c ND, Not done.

genome size are shown in Table 1. In both strains examined, the $\mathrm{G}+\mathrm{C}$ ratio was found to be about $46 \%$, although in one experiment the $T_{m}$ method yielded a slightly lower value.

The calculated genome size varied within the narrow range of $9.4 \times 10^{8}$ and $1.0 \times 10^{9}$ daltons.

\section{DISCUSSION}

The striking discrepancy between the $\mathrm{G}+\mathrm{C}$ content of $46 \%$ of the DNA of strains $122-1 \mathrm{~B} 2$ and $122-1 \mathrm{~B} 3$ of $T$. acidophilum as found in this study and the average value of $27 \%$ for six strains (including 122-1B2 and 122-1B3) reported by Darland et al. (5) and Belly et al. (2) obviously calls for an explanation.

The risk of a secondary contamination of the culture material examined by us would seem to be extremely unlikely for the following reasons: (i) the obvious lack of a plausible source in our laboratory of a contaminant with the very exquisite growth requirements exhibited; (ii) the virtually identical results obtained with the two strains examined, and with two different culture lines of one of these strains; (iii) the subsequent verification of the subcultures of the organisms we studied as T. acidophilum by the laboratory that described the organism and provided the original cultures (passage no. 33 of strain $122-1 \mathrm{~B} 2 / 165$ and no. 38 of strain 122-1B3/153, R. T. Belly, personal communication).

Unfortunately, the difficulties encountered in obtaining consistent growth on solid medium (6) and the large inocula required for the subcultivation of $T$. acidophilum have prevented, so far, the production of cloned cultures by the procedure recommended by the Subcommittee on the Taxonomy of Mycoplasmatales (12). In consequence, the possibility of a primary mixture of different organisms of the available cultures described as T. acidophilum cannot, of course, be excluded with certainty. It may be mentioned, however, that the density gradients and the melting curves obtained in the present study did not provide any evidence, at least, for the possible presence of a mixture of organisms.

It may thus be concluded that at present no definite explanation can be offered to account for the wide discrepancy in the DNA base ratios of $T$. acidophilum as found by the two groups of workers.

As to the possible taxonomic implications of the demonstration of a significantly higher $\mathrm{G}+\mathrm{C}$ content of the DNA of T. acidophilum, it may, finally be stated that these are rather insignificant. Although it is true that the $\mathrm{G}+\mathrm{C}$ content of the majority of the species of the Mycoplasmatales is about the same low level as found by Darland et al. for T. acidophilum, the values hitherto reported do in fact range from 23 to $40 \%$ (7). The demonstration of a $\mathrm{G}+\mathrm{C}$ content of $46 \%$ for T. acidophilum would, therefore, not by itself exclude its classification as a member of the Mycoplasmatales or rather, to quote the Subcommittee on the Taxonomy of the Mycoplasmatales (13), as "an organism loosely attached to the class Mollicutes." It may be further mentioned that the genome size of about $1.0 \times 10^{9}$ for $T$. acidophilum is identical with that of the Acholeplasmataceae, one of the two families presently recognized within the order Mycoplasmatales (1).

\section{REPRINT REQUESTS}

Address reprint requests to: Dr. E. A. Freundt, FAO/WHO Collaborating Centre for Animal Mycoplasmas, University of Aarhus, Bartholin Bldg., DK-8000 Aarhus c, Denmark.

\section{LITERATURE CITED}

1. Bak, A. L., F. T. Black, C. Christiansen, and E. A. Freundt. 1969. Genome size of mycoplasmal DNA. Nature (London) 224:1209-1210.

2. Belly, R. T., B. B. Bohlool, and T. D. Brock. 1973. The genus Thermoplasma. Ann. N. Y. Acad. Sci. 225:94-107.

3. Brock, T. D., K. M. Brock, R. T. Belly, and R. L. Weiss. 1972. Sulfolobus: a new genus of sulfur-oxidizing bacte- 
ria living at low $\mathrm{pH}$ and high temperature. Arch. Mikrobiol, 84:54-68.

4. Christiansen, C., G. Christiansen, and A. L. Bak. 1974. Heterogeneity of mitochondrial DNA from $S a c$ charomyces carlsbergensis: renaturation and sedimentation studies. J. Mol. Biol. 84:65-82.

5. Darland, G., T. D. Brock, W. Samsonoff, and S. F. Conti. 1970. A thermophilic, acidophilic mycoplasma isolated from a coal refuse pile. Science 170:1416-1418.

6. Freundt, E. A. 1972. Discussion, p. 10. In Ciba Foundation Symp. Pathogenic Mycoplasmas. Elsevier/ Excerpta Medica/North-Holland/Associated Scientific Publishers, Amsterdam.

7. Freundt, E. A. 1974. The mycoplasmas, p. 931, 949-952. In R. E. Buchanan and N. E. Gibbons (ed.), Bergey's manual of determinative bacteriology, 8 th ed. The Williams \& Wilkins Company, Baltimore.

8. Langworthy, T. A., P. F. Smith, and W. R. Mayberry. 1972. Lipids of Thermoplasma acidophilum. J. Bacteriol. 112:1193-1200.
9. Marmur, J. 1961. A procedure for the isolation of deoxyribonucleic acid from microorganisms. J. Mol. Biol. 3:208-218.

10. Schildkraut, C. L., J. Marmur, and P. Doty. 1962. Determination of the base composition of deoxyribonucleic acid from its buoyant density in $\mathrm{CsCl}$. J. Mol. Biol. 4:430-443.

11. Smith, P. F., T. A. Langworthy, W. R. Mayberry, and H. E. Hougland. 1973. Characterization of the membranes of Thermoplasma acidophilum. J. Bacteriol. 116:1019-1028.

12. Subcommittee on the Taxonomy of Mycoplasmatales. 1972. Proposal for minimal standards for descriptions of new species of the order Mycoplasmatales. Int. J. Syst. Bacteriol. 22:184-188.

13. Subcommittee on the Taxonomy of Mycoplasmatales. 1974. Minutes of the Meeting, 5 and 6 September 1973. Int. J. Syst. Bacteriol. 24:390-392.

14. Wetmur, J. G., and N. Davidson. 1968. Kinetics of renaturation of DNA. J. Mol. Biol. 31:349-370. 